\title{
The Rate of Growth of some Sea Fishes and their Distribution at Different Ages.
}

\author{
$\mathrm{By}$
}

\section{J. T. Cunningham, M.A.}

Dr. Wemyss Fulton has made an extensive investigation of the distribution of immature sea fishes, and has published his results in the Report of the Scottish Fishery Board for the year 1889. He had at his disposal a sea-going vessel specially adapted to fishery investigations, and his data were obtained exclusively by means of this vessel. As scientific Secretary to the Board Dr. Fulton is attached to the Office in Edinburgh, and the observations he required were made and recorded according to his directions by the naturalists on the Board's steamer "Garland." The conception and the execution of this investigation are both admirable, and it has supplied a great deal of definite knowledge upon subjects of great importance on which previously we knew little or nothing. The enquiry consisted in determining firstly, from the examination of a large number of specimens, the minimum and maximum size of sexually ripe specimens of each species; and secondly, the relative abundance of specimens smaller than this minimum size at various depths and various distance from shore.

The enquiries described in the present paper are to some extent similar to Dr. Fulton's, but in the main they are different both in object and in method. My first object was as far as possible to ascertain something of the rate of growth of sea-fishes of various species. With this purpose, I have searched for young specimens in all possible ways, and have measured and preserved all I could meet with. Some have been taken with the shrimp-trawl worked from our little steam-launch in Plymouth Sound and the neighbouring bays, some in the tow-net. I have also collected specimens from the deep-sea trawl of the professional trawlers, and from the hauls of ground seines. During the summer of the present year, I have been authorised to hire steamers in order to collect in deep water at some distance from land, and have trawled at various

NEW SERIES.-VOL. II, NO. II. 
depths with the shrimp-trawl and a small-meshed otter-trawl, and have also worked a large tow-net, 8 feet by 6 feet in area at the mouth, at various distances from the coast. Knowing the spawning time of each species I have been able to determine the age of the young specimens collected in a number of cases with more or less certainty. Often there is no doubt as to the age within a month or so of young specimens of the same year's brood, and it is often possible to say that small fish which are too large to be derived from the last spawning period, for instance those collected at the spawning period itself or a little later, must be a year old or a little over. But it is difficult in this way to ascertain the maximum growth for one year, since a number of specimens of one species often form a continuous series in size, and it becomes difficult or impossible to say where those of one year old end and those of two years begin.

In order to get more certainty on the question, I have been rearing specimens of known age of as many species as possible in the tanks of the aquarium. The first results of these experiments were published in this Journal, vol. i, p. 370. Many of the flounders and other fish mentioned there are still alive. It is, of course, a question in the case of each species how far the growth of specimens in captivity is normal, whether it exceeds or falls short of the growth of those living in the free state. This question can only be answered by comparing the size of captive specimens with that of young specimens collected from the sea at various times of the year.

I have recorded the place of capture as well as the size of the specimens collected, and am able therefore in some cases to confirm and in others to add to the results obtained by Dr. Fulton. In a few cases I have had opportunities of determining the minimum size of ripe specimens with results which sometimes differ from Dr. Fulton's, a difference doubtless due in part to the difference of the districts in which our observations have been made.

Another subject I have discussed is the relation between age and sexual maturity. It is not at present known whether flat fishes for instance begin to breed at one year of age or at two, or whether some breed at one year and others at two according to the size they reach in the time. Some species again may have a more uniform growth than others, and all breed at the end of their first year, while other species do not breed till a later age.

I have given below, in tabular form, the details I have collected up to the present time concerning the several species. The majority of the species considered, belong to the families Pleuronectidø and Gadidæ, and I have more data referring to the flat fishes than to any other species. With the exception of Caranx trachurus all the 
species included in this paper are trawl-fishes. Each table is followed by a short commentary, and at the end of the paper I have summarised and compared together the results brought out by the tables.

Pleuronectes flesus, the Flounder. Specimens reared in the Aquarium.

\begin{tabular}{|c|c|c|c|c|c|}
\hline Date. & $\begin{array}{l}\text { Number of } \\
\text { specimens. }\end{array}$ & $\begin{array}{l}\text { Length in } \\
\text { centimetres. }\end{array}$ & $\begin{array}{l}\text { Length in } \\
\text { inches. }\end{array}$ & Age. & Remarks. \\
\hline $\begin{array}{l}\text { May, 7, } 1890 \\
\text { Aug. 19, } 1890\end{array}$ & $\begin{array}{c}200-300 \\
2\end{array}$ & $\begin{array}{l}1 \cdot 15-1 \cdot 2 \\
6 \cdot 7-8 \cdot 0\end{array}$ & $2 \cdot 6-3 \cdot 2$ & $\begin{array}{l}\text { About } 1 \text { month } \\
\text { to } 2 \text { months } \\
4 \text { to } 5 \text { months }\end{array}$ & $\begin{array}{l}\text { Obtained in Mevagissey Har- } \\
\text { bour at low tide. } \\
\text { Only two measured. }\end{array}$ \\
\hline April 4, 1891 & 18 & $4 \cdot 0-16 \cdot 3$ & $1 \cdot 6-6 \cdot 0$ & 1 year & Kept in a tank $5 \mathrm{ft}$. by $2 \frac{1}{2} \mathrm{ft}$. \\
\hline ” & 20 & $5 \cdot 0-17 \cdot 4$ & & 1 year & $\begin{array}{l}\text { Kept in another tank of the } \\
\text { same size. }\end{array}$ \\
\hline$"$ & 13 & $5 \cdot 5-19 \cdot 0$ & $2 \cdot 2-7 \frac{1}{2}$ & 1 year & $\begin{array}{l}\text { Kept the latter part of the } \\
\text { time in a tank } 18 \mathrm{ft} \text {. by } 3 \frac{1}{2} \mathrm{ft} \text {, } \\
\text { by } 2 \mathrm{ft} \text {. deep. The smallest } \\
\text { weighed } \frac{1}{4} \text { oz., the largest } \\
3 \frac{1}{8} \text { oz. }\end{array}$ \\
\hline Sept. 1, 1891 & 3 & $17 \cdot 8-20 \cdot 8$ & $7 \cdot 0-8 \cdot 2$ & 1 year 6 months & $\begin{array}{l}\text { Kept in a tank } 2 \mathrm{ft} \text {. by } 1 \mathrm{ft} \text {. } \\
\text { in area, and died from an } \\
\text { accident to the water. }\end{array}$ \\
\hline
\end{tabular}

The above table gives the growth actually observed in a large number of specimens kept in captivity and abundantly supplied with food. The most striking feature of the result is the very great variation in growth among these individuals, spawned at the same season, and therefore not differing by more than a few weeks in age. Whether there is as much variation under natural conditions is a question that immediately suggests itself. It is evident there is considerable variation in the rate of growth in nature, from the difficulty of distinguishing in a large number of fish those of one year's, two years', and three years' growth. It is not difficult to recognise with certainty young fish only a few weeks or months old; but the individuals of a given species brought up in numbers at a single haul of the great beam-trawl form usually a regular series of sizes, so that it is difficult if not impossible to separate definitely those which are one year old from those which are two, and those which are two years from those which are three.

Another point of interest is the relation of age to sexual maturity. According to Dr. Fulton's investigations, the smallest ripe flounder is 7 inches long. Now some, namely two out of fifty-one specimens, of my captive flounders had reached and passed this limit 
of size in one year's growth. But these specimens were not ripe, and the proportion of specimens of this size is so small, that I think it may fairly be concluded that the flounder does not breed at the end of its first year. Of course, it is possible that the largest specimens one year old breed, while the smaller are still sexually immature; but the evidence of my captive specimens is against this. It seems probable, therefore, that the flounder does not begin to breed until it is two years old, when its length would probably be from 7 to 9 or 10 inches. The largest flounder observed by Dr. Fulton was $16 \frac{1}{2}$ inches long. The increase in length per annum must of course diminish with every year of age, even if the rate of increase in weight were to remain uniform, simply because the weight is proportional to the cubic dimensions of the fish, and probably the rate of increase in weight also diminishes with age. Therefore, a flounder from 12 to 16 inches in length is in all probability at least three years old and may be many more.

Pleuronectes flesus, the Flounder. Specimens obtained from the Sea.

\begin{tabular}{|c|c|c|c|c|c|}
\hline Date. & $\begin{array}{l}\text { Number of } \\
\text { specimens. }\end{array}$ & $\begin{array}{l}\text { Length in } \\
\text { centimetres. }\end{array}$ & $\begin{array}{l}\text { Length in } \\
\text { inches. }\end{array}$ & Calculated age. & Locality and remarks. \\
\hline $\begin{array}{l}\text { May } 7,1890 \\
\text { May } 31,1889 \\
\text { June } 15,1889 \\
\text { April } 8,1891 \\
\text { Oct. } 15,1890\end{array}$ & $\begin{array}{c}200-300 \\
\text { A number } \\
\Rightarrow \\
6 \\
3 \\
2\end{array}$ & $\begin{array}{c}1 \cdot 15-1 \cdot 2 \\
1 \cdot 1-1 \cdot 9 \\
1 \cdot 2-2 \cdot 8 \\
14 \cdot 2-19 \cdot 0 \\
18 \cdot 1-21 \cdot 3 \\
26 \cdot 2-27 \cdot 0\end{array}$ & $\begin{array}{c}\frac{1}{2} \text { inch } \\
\\
\frac{1}{2}-\frac{3}{4} \\
\frac{1}{2}-1 \cdot 1 \\
5 \cdot 6-7 \cdot 5 \\
7 \cdot 1-8 \cdot 4 \\
10 \cdot 3-10 \cdot 6\end{array}$ & $\begin{array}{l}\text { About } 1 \text { to } 2 \\
\text { months } \\
2 \text { to } 3 \text { months } \\
2 \frac{1}{2} \text { to } 3 \frac{1}{2} \text { months } \\
1 \text { year } \\
1 \text { year } 7 \text { months } \\
2 \text { years } 7 \text { months }\end{array}$ & $\begin{array}{l}\text { Mevagissey Harbour. } \\
\text { " " } \\
\text { Taken by seine in Catwater. } \\
\text { Taken by seine in Hamoaze. } \\
\text {," }\end{array}$ \\
\hline
\end{tabular}

The data here are very insufficient, and I hope to add largely to their number in future. But I think it is evident that the flounders taken on April 8th, 1891, in the Cattewater, were just over one year old, and had grown to about the same size as the larger among the specimens kept in our tanks. It seems, therefore, that the growth of this species observed in captivity does not differ very much from that of specimens living in freedom. Whether in a state of nature specimens ever reach such a small size in one year as the smallest of my captive specimens $I$ am as yet unable to say. But it must be remembered that the competition for food in a small tank containing a large number of specimens is very great, so that individuals which possess a little superiority in size and activity to start with, probably increase that superiority continually by seizing the greater part of the food before the smaller ones can get it. No doubt there is competition in the natural state, but at any rate the 
individuals on the sea bottom have a much greater area to wander over.

With regard to distribution it is noteworthy that I have taken no flounders under 7 inches long except in the estuaries of Cattewater and the Hamoaze, although I have seen numbers of ripe flounders brought up in the trawl on the ground inside the Eddystone from a depth of 25 to 28 fathoms. Dr. Fulton also failed to find any small flounders in the results of the Garland's fishing at various depths and distances from the shore with a small-meshed trawl. It seems pretty certain that the flounder in its immature state is confined to inlets and especially estuaries, where the water is more or less brackish. It certainly spawns in the open sea up to depths of 30 fathoms; but even adults are found far up such estuaries as the Firth of Forth, and the Cattewater at Plymouth.

Pleuronectes platessa, the Plaice.

\begin{tabular}{|c|c|c|c|c|c|}
\hline $\begin{array}{l}\text { Date of collec- } \\
\text { tion. }\end{array}$ & $\begin{array}{l}\text { Number of } \\
\text { specimens. }\end{array}$ & $\begin{array}{l}\text { Length in } \\
\text { centimetres. }\end{array}$ & $\begin{array}{l}\text { Length in } \\
\text { inches. }\end{array}$ & Calculated age. & Locality and remarks. \\
\hline June 13,1889 & 1 & $5 \cdot 1$ & $2 \cdot 0$ & 4 months & $\begin{array}{c}\text { Whitsand Bay, } 5 \text { to } 7 \\
\text { fathoms. Shrimp trawl. }\end{array}$ \\
\hline June 17,1889 & 39 & $3 \cdot 5-5 \cdot 9$ & $1 \cdot 4-2 \cdot 3$ & 3 or 4 months & व, \\
\hline t. 28,1889 & 1 & $6 \cdot 3$ & 2.5 & 6 months & Sutton Pool. \\
\hline b. 13,1889 & 2 & $8 \cdot 0,8 \cdot 3$ & $3 \cdot 1,3 \cdot 3$ & 1 year & Cattewater. \\
\hline Feb. 26,1889 & 1 & $9 \cdot 4$ & $3 \cdot 7$ & 1 year & Entrance of Cattewater. \\
\hline Feb. 27,1889 & 1 & $8 \cdot 9$ & 3.5 & 1 year & $\begin{array}{l}\text { Cawsand Bay, } 3 \text { to } 5 \\
\text { fathoms. }\end{array}$ \\
\hline May 16,1889 & 10 & $11 \cdot 2-17 \cdot 7$ & $4 \cdot 4-7 \cdot 0$ & $\begin{array}{l}1 \text { year and } \\
\text { months }\end{array}$ & 3 Cattewater, in small seine. \\
\hline May 24, 1889 & 1 & $15 \cdot 5$ & $6 \cdot 1$ & , & Cattewater. \\
\hline Sept. 18,1891 & 1 & $20 \cdot 7$ & $8 \cdot 2$ & 1 year and & $\begin{array}{l}75 \text { to } 8 \text { miles } \mathrm{S} \text {. of Eddy- } \\
\text { stone, } 35 \text { fathoms. }\end{array}$ \\
\hline Oct. 15,1890 & 7 & $19 \cdot 5-24 \cdot 8$ & $7 \cdot 7-9 \cdot 8$ & 1 year and & 8 Hamoaze, in small seine. \\
\hline Dec. 10,1889 & 1 & $22 \cdot 4$ & $8 \cdot 8$ & 1 year and 1 & 10 Cattewater. \\
\hline April 19, 1891 & 2 & 25 & $9 \cdot 8$ & 2 years & $\begin{array}{l}\text { Professional trawler, E. of } \\
\text { Eddystone, } 30 \text { fathoms. }\end{array}$ \\
\hline Sept. 8,1891 & 1 & $22 \cdot 2$ & $8 \cdot 7$ & 1 year and & $7]$ s.w of Rame Head. \\
\hline$"$ & 6 & $27 \cdot 5-31 \cdot 5$ & $10 \cdot 8-12 \cdot 4$ & $\begin{array}{l}2 \text { years and } \\
\text { months }\end{array}$ & $7 \int 25$ fathoms, otter-trawl. \\
\hline
\end{tabular}

It may seem that I have estimated the age of the specimens in the last entry of the table too highly, but it must be remembered that the plaice reaches by no means so large a size on the southwest coast of England as it does on the east coast. In fact, in the neighbourhood of Plymouth the plaice is not very much larger than the flounder. Dr. Fulton gives the maximum size of the plaice as 
28 inches, but I think 20 inches is about the maximum at Plymouth, and the usual size is 15 to 18 inches. I do not think, therefore, that this species could reach 12 inches in less than two years. My observations fully agree with those of Dr. Fulton in regard to the distribution of young plaice, all those I have obtained under 9 inches having come from Whitsand Bay, 3 to 7 fathoms, or from the estuaries opening into Plymouth Sound. The smallest ripe plaice I have seen was 25 c.m. or 9.8 inches long, and this was a male, while Dr. Fulton finds the lowest limit in size of mature individuals to be 12 inches. This again illustrates the difference with respect to this species between the south coast and the east coast.

From my results and Dr. Fulton's together I think there is very strong evidence that the plaice does not begin to breed till it is two years old (and over 8 inches long on the south coast), that for the first eighteen months of its life it resides in estuaries and inlets under 10 fathoms in depth, and that it only migrates to deeper water when it is nearly two years old, shortly before it begins to breed for the first time.

Pleuronectes limanda, the Dab.

\begin{tabular}{|c|c|c|c|c|c|}
\hline Date. & $\begin{array}{l}\text { Number of } \\
\text { specimens. }\end{array}$ & $\begin{array}{c}\text { Length in } \\
\text { centimetres. }\end{array}$ & $\begin{array}{l}\text { Length in } \\
\text { inches. }\end{array}$ & Calculated age. & Locality and remarks. \\
\hline June 14, 1890 & 1 & $1 \cdot 05$ & 0.4 & About 3 months & Cawsand Bay, 3 to $5 \mathrm{fms}$. \\
\hline June 17,1889 & 11 & $3-3 \cdot 4$ & $1 \cdot 2-1 \cdot 4$ & & Whitsand Bay, 5 to $7 \mathrm{fms}$. \\
\hline June 25, 1889 & 7 & $1 \cdot 7-3 \cdot 2$ & $0 \cdot \overline{7}-1 \cdot 3$ & $"$ & Cawsand Bay. \\
\hline July 9,1891 & 2 & $1 \cdot 6-1 \cdot 7$ & $0.6-0.7$ & " & $\begin{array}{l}\text { Two miles N. of Eddystone, } \\
\text { fine meshed shrimp trawl. }\end{array}$ \\
\hline Sept. 4, 1890 & 8 & $3 \cdot 3-5 \cdot 1$ & $1 \cdot 3-2$ & About 6 months & W. of Rame Head, $20 \mathrm{fms}$. \\
\hline Oet. 3,1889 & 1 & 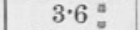 & $1 \cdot 4$ & About $7 \mathrm{n}$ & Cawsand Bay. \\
\hline Dec. 10,1889 & 5 & $5 \cdot 7-11$ & $2 \cdot 2-4 \cdot 3$ & About 9 months & Cattewater. \\
\hline Feb. 13,1890 & 7 & $2 \cdot 6-9 \cdot 5$ & $1-3 \cdot 7$ & About 11 months & Cattewater. \\
\hline Feb. 27,1890 & 2 & $5 \cdot 7,6 \cdot 1$ & $2 \cdot 2,2 \cdot 4$ & & Cawsand Bay. \\
\hline Apr. 3,1891 & 8 & $5 \cdot 7-12 \cdot 6$ & $2 \cdot 2-5$ & About 13 months & $\begin{array}{l}\text { Cattewater. With these } \\
\text { was } 1 \text { specimen } 17 \cdot 2 \mathrm{~cm} \text {., } \\
\text { probably } 2 \text { years old. }\end{array}$ \\
\hline Apr. 30, 1891 & 5 & $5 \cdot 0-6 \cdot 0$ & $2-2 \cdot 4$ & & Plymouth Sound. \\
\hline May 10,1889 & 18 & $4 \cdot 7-9 \cdot 1$ & $1 \cdot 8-3 \cdot 6$ & About 14 months & Cattewater. \\
\hline May 8 & 2 & $7 \cdot 9$ & $3 \cdot 1$ & , & Cawsand Bay. \\
\hline May 6,1889 & 2 & $-7 \cdot 9$ & $3 \cdot 1$ & & Whitsand Bay. \\
\hline Apr. 19, 1891 & 3 & $11 \cdot 5-13 \cdot 5$ & $4 \cdot 5-5 \cdot 3$ & About 1 year & $\begin{array}{l}\text { Large trawl, E. of Eddy- } \\
\text { stone. Unripe males. }\end{array}$ \\
\hline & 6 & $14 \cdot 4-18 \cdot 3$ & $5 \cdot 7-7 \cdot 2$ & Probably 2 years & Ripe Males. \\
\hline & 2 & $17 \cdot 0-18 \cdot 8$ & $6 \cdot 7,7 \cdot 4$ &, & Females, 1 ripe, 1 nearly so. \\
\hline $\begin{array}{r}\text { Aug. 20, } \\
,\end{array}$ & 22 & $14-16$ & $5 \cdot 5-6.3$ & Probably 1 year & Trawler, 5 miles $\mathrm{S}$. of \\
\hline , & 30 & $16-18$ & $6 \cdot 3-7 \cdot 1\}$ & and 5 months & Eddystone \\
\hline ", & 36 & $18-20$ & $7 \cdot 1-7 \cdot 9$ & & \\
\hline$"$ & 5 & $20-22$ & $7 \cdot 9-8 \cdot 7\}$ & Probably 2 years & \\
\hline & 2 & $22-24$ & $8 \cdot 7-9 \cdot 5\}$ & and 5 months & \\
\hline Dec. 10,1889 & 5 & $14-18 \cdot 5$ & $5 \cdot 5-7 \cdot 3$ & 1 year 9 months & $\begin{array}{l}\text { Cattewater. Weight of the } \\
\text { largest } 2 \mathrm{oz} .6 \text { drms. }\end{array}$ \\
\hline $\begin{array}{c}\text { Sept. 18, } 1891 \\
,\end{array}$ & $\begin{array}{l}49 \\
48\end{array}$ & $\begin{array}{c}12 \cdot 5-19 \cdot \\
19-26\end{array}$ & $\begin{array}{c}4 \cdot 9-7 \cdot 5 \\
7 \cdot 5-10 \cdot 2\end{array}$ & $\left.\begin{array}{l}1 \text { year } 6 \text { mos. } \\
2 \text { years } 6 \text { mos. }\end{array}\right\}$ & $\begin{array}{l}\text { From } 2 \text { trawlers working } 5 \\
\text { to } 8 \text { miles } \mathrm{S} \text {. of Eddystone. }\end{array}$ \\
\hline
\end{tabular}


According to Dr. Fulton the smallest ripe dab was $5 \frac{1}{2}$ inches long, and the maximum specimen observed 14 inches long. The smallest ripe specimen seen by me was a male $5 \cdot 7$ inches in length; the smallest ripe female I have seen was 6.7 inches. The dab spawns in March and April, and in reckoning the ages in the above table I have counted from the month of March. It is certain that the ages given in the above table up to the entry for May 6th, 1889, are correct, and we see, from the sizes of those taken in the summer and autumn, the growth of the fish spawned the same year, while those taken between Christmas and May must be derived from the brood of the previous year, even the smallest taken in May, 1.8 inches, being too large to be attributed to the spawning of the same spring. Thus we find that a dab just over a year old may be as small as 1.8 inches in length; a conclusion not surprising in view of the fact that some of the flounders reared in captivity were only $1 \cdot 6$ inches at the same age. The maximum growth exhibited by this species in a year is more diffcult to determine, but considering the case of the flounder we need have no doubt that the specimens 5 inches long, taken on April 3rd, were only just over a year old. Some specimens may very likely reach a greater size than this in the same time. The maximum observed in the flounder was $7 \frac{1}{2}$ inches, and as the adult flounder is 2 inches longer than the adult dab, we may provisionally conclude that $5 \frac{1}{2}$ inches is about the maximum length reached by a dab in one year. Thus we see that the minimum size, compatible with reproduction, may be reached or slightly surpassed at the end of the first year, but it is certain that the great majority of dabs at one year old are below that size. And it is not certain that those which are large enough to breed at the end of one year, do actually breed then. On the other hand the great majority of even the smallest ripe specimens are of a size that in all probability is not reached by any individuals in less than two years.

If we examine the entries of specimens obtained from the professional trawlers, we get some interesting results. In the first place we find that the smallest specimens captured are about $4 \frac{1}{2}$ inches long. The breadth corresponding to this length is little over $1 \frac{1}{2}$ inches. The meshes of the great beam-trawl, as used at Plymouth, are 4 inches square at the mouth, diminishing to $1 \frac{1}{2}$ inches square at the cod end. Thus there is a close correspondence between the size of the mesh at the cod end and the smallest fish caught.

We may roughly estimate the growth of the dab in successive years as follows : 


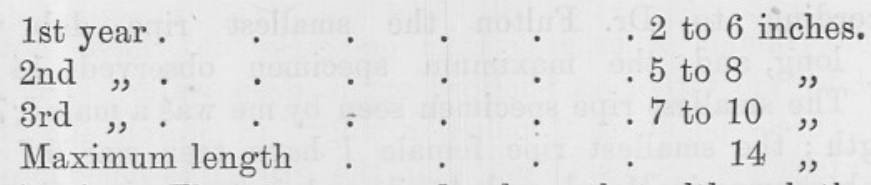

Distribution.-The above records show that although the young dabs under one year old, and 6 inches in length, are common everywhere in shallow water, penetrating even to the estuaries such as the Cattewater, where the greatest depths is only 3 fathoms, they are also taken out near the Eddystone at a depth of about 30 fathoms. In the latter region I took two specimens $\cdot 6$ and $\cdot 7$ inches long in July. These were taken in a shrimp trawl lined with mosquito-netting, having a mesh of about $\frac{1}{4}$ inch. The professional trawlers do not, however, catch specimens of the first year, because their mesh is too large. These conclusions as to the distribution are in complete agreement with those of Dr. Fulton.

Pleuronectes microcephalus, the Lemon Sole, or Merry Sole.

\begin{tabular}{|c|c|c|c|c|c|}
\hline Date. & $\begin{array}{l}\text { Number of } \\
\text { specimens. }\end{array}$ & $\begin{array}{l}\text { Length in } \\
\text { centimetres. }\end{array}$ & $\begin{array}{l}\text { Length in } \\
\text { inches. }\end{array}$ & Calculated age. & Locality and remarks. \\
\hline Nov. 4,1890 & 4 & $15 \cdot 5-17 \cdot 5$ & $6 \cdot 1-6 \cdot 9$ & 1 year 5 months & Firth of Forth; sent me \\
\hline Aug. 20, 1891 & 5 & $16 \cdot 8-20 \cdot 1$ & $6 \cdot 6-7 \cdot 9$ & 1 year 4 months & $\begin{array}{l}4 \text { or } 5 \text { miles S. of Eddy- } \\
\text { stone, from professional } \\
\text { trawler. }\end{array}$ \\
\hline April 19, 1891 & 5 & $16 \cdot 3-23 \cdot 6$ & $6 \cdot 4-9 \cdot 3$ & 2 years & $\begin{array}{l}\text { East of Eddystone, profes- } \\
\text { sional trawler. All ripe } \\
\text { males. }\end{array}$ \\
\hline
\end{tabular}

The above data are all I have hitherto been able to collect concerning this species. The lemon sole spawns in May and June off the Firth of Forth, and in April and May off Plymouth. It is manifestly impossible that the young should reach a length of over 6 inches between May and November, since the adult lemon sole is but little larger than the adult flounder, and its growth not likely to be more rapid. Therefore the specimens taken in the Firth of Forth in November, and at Plymouth in August, are probably in their second year. As to the age of those taken in April, they might have reached the size of 6 inches in a year, but could scarcely have reached 9.3 inches in that time. If the lemon sole can become mature in one year some of these may have been one year old, and the larger ones two years.

It is noticeable that lemon soles only 6.4 inches long are sexually mature at Plymouth, while the smallest observed by Dr. Fulton to be ripe were $8 \frac{1}{2}$ inches long. 
Hitherto, lemon soles, less than one year old, have not been obtained by me either in shallow or in deep water. Dr. Fulton obtained three specimens 2 inches in length in March and May, in about 20 fathoms. This shows that the growth is not more rapid than that of the flounder, since these specimens were ten to twelve months old.

Solea vulgaris, the Sole.

\begin{tabular}{|c|c|c|c|c|c|}
\hline $\begin{array}{l}\text { Date of } \\
\text { collection. }\end{array}$ & $\begin{array}{l}\text { Number of } \\
\text { specimens. }\end{array}$ & $\begin{array}{l}\text { Length in } \\
\text { centimetres. }\end{array}$ & $\begin{array}{l}\text { Length in } \\
\text { inches. }\end{array}$ & Calculated age. & Locality and remarks. \\
\hline May 15,1889 & 15 & $1 \cdot 2-1 \cdot 5$ & $0.5-0.6$ & About 1 month & Mavagissey Harbour, be- \\
\hline ", 10,1889 & 3 & $16 \cdot 8-19 \cdot 5$ & $6 \cdot 6-7 \cdot 7$ & 1 year & $\begin{array}{l}\text { Cattewater, taken in shrimp } \\
\text { trawl. }\end{array}$ \\
\hline , 9,1889 & 1 & $17 \cdot 6$ & $6 \cdot 9$ & & Under Citadel, shrimp trawl \\
\hline June 17,1889 & 1 & $19 \cdot 8$ & $7 \cdot 8$ & $\begin{array}{c}1 \text { year and } 2 \text { or } \\
3 \text { months }\end{array}$ & $\begin{array}{l}\text { Whitsand Bay, } 3 \text { to } 5 \\
\text { fathoms. }\end{array}$ \\
\hline July 27,1889 & 4 & $13 \cdot 1-19 \cdot 7$ & $5 \cdot 2-7 \cdot 8$ & 1 year and 3 or & Malpas, Falmouth River. \\
\hline Sept. 19, 1890 & 2 & $16 \cdot 0,16 \cdot 2$ & $6 \cdot 3,6 \cdot 4$ & 1 year and $6 \mathrm{mos}$. & Cattewater, seine. \\
\hline April 19, 1891 & 1 & $24 \cdot 0$ & $9 \cdot 5$ & 2 years & $\begin{array}{l}\text { Large trawl, E. of Eddy- } \\
\text { stone. }\end{array}$ \\
\hline
\end{tabular}

Most of these data were given in my "Treatise on the Common Sole," but I have slightly modified my interpretation of them. The specimens taken in the Sound up to $19 \cdot 7 \mathrm{~cm}$. in length I formerly considered to be two years old, but my observations on the flounder in captivity show that some soles probably reach this length at the beginning of their second year.

Solea lascaris, the French Sole, or Sand Sole.

\begin{tabular}{|c|c|c|c|c|c|}
\hline $\begin{array}{l}\text { Date of collec- } \\
\text { tion. }\end{array}$ & $\begin{array}{l}\text { Number of } \\
\text { specimens. }\end{array}$ & $\begin{array}{l}\text { Length in } \\
\text { centimetres. }\end{array}$ & $\begin{array}{l}\text { Length in } \\
\text { inches. }\end{array}$ & Calculated age. & Locality and remarks. \\
\hline Sept. 28, 1889 & 1 & $9 \cdot 0$ & $3 \cdot 5$ & 4 months & $\begin{array}{l}\text { Whitsand Bay, about } 5 \\
\text { fathoms. }\end{array}$ \\
\hline March, 1890 & 1 & $5 \cdot 0$ & $2 \cdot 0$ & 10 months & $\begin{array}{l}\text { Off Falmouth, collected by } \\
\text { Mr. Vallentin. }\end{array}$ \\
\hline June 17,1889 & 3 & $17 \cdot 2-19 \cdot 2$ & $6 \cdot 8-7 \cdot 6$ & 1 year & $\begin{array}{l}\text { Whitsand Bay, } 5 \text { to } 7 \\
\text { fathoms. }\end{array}$ \\
\hline
\end{tabular}

This species is not common, and it is therefore difficult to get more than an occasional specimen; the size of the adult is about the same as that of the common sole, and the above estimated ages are based on comparison with that of my captive flounders. 
Solea lutea, the Little Sole.

\begin{tabular}{|c|c|c|c|c|c|}
\hline $\begin{array}{l}\text { Date of } \\
\text { collection. }\end{array}$ & $\begin{array}{l}\text { Number of } \\
\text { specimens. }\end{array}$ & $\begin{array}{l}\text { Length in } \\
\text { centimetres. }\end{array}$ & $\begin{array}{l}\text { Length in } \\
\text { inches. }\end{array}$ & Calculated age. & Locality and remarks. \\
\hline June 25,1890 & 1 & 5 & 2 & 1 year & $\begin{array}{l}\text { Cawsand Bay, } 3 \text { to } 5 \text { fath- } \\
\text { oms, shrimp trawl. }\end{array}$ \\
\hline Sept. 21, 1891 & 7 & $7 \cdot 4-8 \cdot 5$ & $2 \cdot 9-3 \cdot 4$ & 1 year 3 months & s Cawsand Bay, shrimp trawl. \\
\hline " 8,1891 & 1 & 11.5 & 4.5 & 2 years 3 months & $\begin{array}{l}\text { S.W. of Rame Head, } 20 \\
\text { fathoms. }\end{array}$ \\
\hline $\begin{array}{r}3,1891 \\
\text { Nov. } 26,1889\end{array}$ & $\begin{array}{l}2 \\
1\end{array}$ & $\begin{array}{c}10 \cdot 8,11 \cdot 6 \\
11 \cdot 9\end{array}$ & $\begin{array}{c}4: 3,4: 5 \\
4: 7\end{array}$ & 2 years 5 months & sawsand Bay. " \\
\hline
\end{tabular}

According to Dr. Fulton, this species spawns when it is $3 \frac{3}{4}$ inches long, a length which seems to me to be reached at the end of two years. The fish rarely exceeds 5 inches in length, and specimens nearly as large as this occur occasionally in the shallow water of Cawsand Bay. But the adults are more commonly found farther from shore at depths up to 30 fathoms.

Solea variegata, the Thickback.

\begin{tabular}{|c|c|c|c|c|c|}
\hline $\begin{array}{c}\text { Date of } \\
\text { collection. }\end{array}$ & $\begin{array}{l}\text { Number of } \\
\text { specimens. }\end{array}$ & $\begin{array}{c}\text { Length in } \\
\text { centimetres. }\end{array}$ & $\begin{array}{l}\text { Length in } \\
\text { inches. }\end{array}$ & Calculated age. & Locality and remarks. \\
\hline July 9,1891 & 2 & $4 \cdot 5,4 \cdot 6$ & 1.8 & 3 months & $\begin{array}{l}2 \text { miles N. of Eddystone. } \\
\text { Trawl of mosquito-net- } \\
\text { ting. }\end{array}$ \\
\hline Sept. 8,1891 & 1 & $12 \cdot 7$ & 5 & $\begin{array}{l}1 \text { year and } \\
5 \text { months }\end{array}$ & $\begin{array}{l}\text { Off Whitsand Bay, } 20 \\
\text { fathoms. }\end{array}$ \\
\hline Dec. 9,1889 & 1 & $10 \cdot 1$ & 4 & $\begin{array}{l}1 \text { year and } \\
8 \text { months }\end{array}$ & $\begin{array}{l}\text { Near Eddystone, from } \\
\text { trawler. }\end{array}$ \\
\hline Aug. 20, 1891 & 2 & $14 \cdot 5,15 \cdot 2$ & $5 \cdot 7,6 \cdot 3$ & $\begin{array}{l}2 \text { years and } \\
4 \text { months }\end{array}$ & $\begin{array}{l}5 \text { miles S. of Eddystone, } \\
\text { from trawler. }\end{array}$ \\
\hline
\end{tabular}

As this is a small species the maximum length observed by me being $21.5 \mathrm{~cm}$., or $8 \frac{1}{2}$ inches, its growth is probably proportional; the spawning takes place in April and May. It will be observed that the only specimens under 2 inches long were obtained in deep water six miles from land.

I will take this opportunity of recording some observations I made on the relations of the sexes to one another in size and number in this species. On April 19th, 1889, on board a Plymouth trawling smack, I examined a large number of thickbacks taken in two or three hauls of the trawl. The result was as follows :

Number of males 34 .-Largest measured $19 \cdot 2 \mathrm{~cm}$. long. Middlesized specimen $17 \cdot 0 \mathrm{~cm}$. 
Number of females 179.-Largest measured $21.5 \mathrm{~cm}$. long. Middle-sized specimen $19 \cdot 3 \mathrm{~cm}$.

Thus the females in this species are both larger and more numerous than the males, as was found to be the case by Dr. Fulton in many other species of flat fishes. The proportion between the sexes is 526 females to 100 males, or one male to five females nearly. The ratio of females to males is even higher than this, according to Dr. Fulton, in the long rough dab, Hippoglossoides limandoides.

Rhombus maximus, the Turbot.

\begin{tabular}{|c|c|c|c|c|c|}
\hline $\begin{array}{l}\text { Date of } \\
\text { collection. }\end{array}$ & $\begin{array}{l}\text { Number of } \\
\text { specimens. }\end{array}$ & $\begin{array}{l}\text { Length in } \\
\text { centimetres. }\end{array}$ & $\begin{array}{l}\text { Length in } \\
\text { inches. }\end{array}$ & Calculated age. & Locality and remarks. \\
\hline Aug., year? & 6 & $2 \cdot 4-3 \cdot 8$ & $\cdot 95-1 \cdot 5$ & About 1 month & $\begin{array}{l}\text { Collected at surface in } \\
\text { Mevagissey Harbour by } \\
\text { Mr. Dunn. }\end{array}$ \\
\hline Aug. 11, 1888 & 1 & $3 \cdot 7$ & $1 \cdot 45$ & " & $\begin{array}{l}\text { At surface in Plymouth } \\
\text { Sound. }\end{array}$ \\
\hline Sept. 1, 1891 & 3 & $1 \cdot 5-2$ & $\cdot 6-8$ & About 3 weeks & $\begin{array}{l}\text { Surface at wharf, Catte- } \\
\text { water. }\end{array}$ \\
\hline Sept. 4, 1891 & 9 & $1 \cdot 5-2 \cdot 5$ & $\cdot 6-1 \cdot 0$ & $\begin{array}{l}3 \text { weeks to } \\
1 \text { month }\end{array}$ & $\begin{array}{l}\text { Surface at West Hoe Pier, } \\
\text { Plymouth Sound. }\end{array}$ \\
\hline Sept. 8, 1891 & 1 & 2.5 & $1 \cdot 0$ & About 1 month & $\begin{array}{l}\text { Tow-net surface, S.W. of } \\
\text { Mewstone, about } 4 \text { miles } \\
\text { from Plymouth Break- } \\
\text { water. }\end{array}$ \\
\hline June 17,1889 & 3 & $23-34$ & $9-12$ & 11 months & $\begin{array}{l}\text { Whitsand Bay, } 3 \text { to } 5 \\
\text { fathoms. }\end{array}$ \\
\hline
\end{tabular}

It will be seen from the above that the young turbot in process of metamorphosis, and swimming horizontally at the surface, occur at Plymouth and the neighbourhood in August and the beginning of September, while the brill at the same stage occur in May and June. It is thus evident that the turbot spawns later than the brill. I have estimated the age of these specimens about an inch long at one month, though they may be a little more. The spawning period, therefore, occurs in June and July. Wenckebach, in Holland, found turbot ripe in July.

I have no stages between the pelagic stage just mentioned and the small turbot, of 9 to 12 inches, obtained in Whitsand Bay in June, 1889. This year, although I have several times trawled in Whitsand Bay, I have obtained no specimens of this species. At present I see no reason to suppose that the specimens of 9 to 12 inches were more than one year old; it is certain that they were not less, as the spawning takes place in June and July. The largest turbot recorded by Dr. Fulton was 28 inches long, and the smallest mature was 18 inches long. It is probable that a turbot 2 feet in length is at least four years old. 
Rhombus lævis, the Brill.

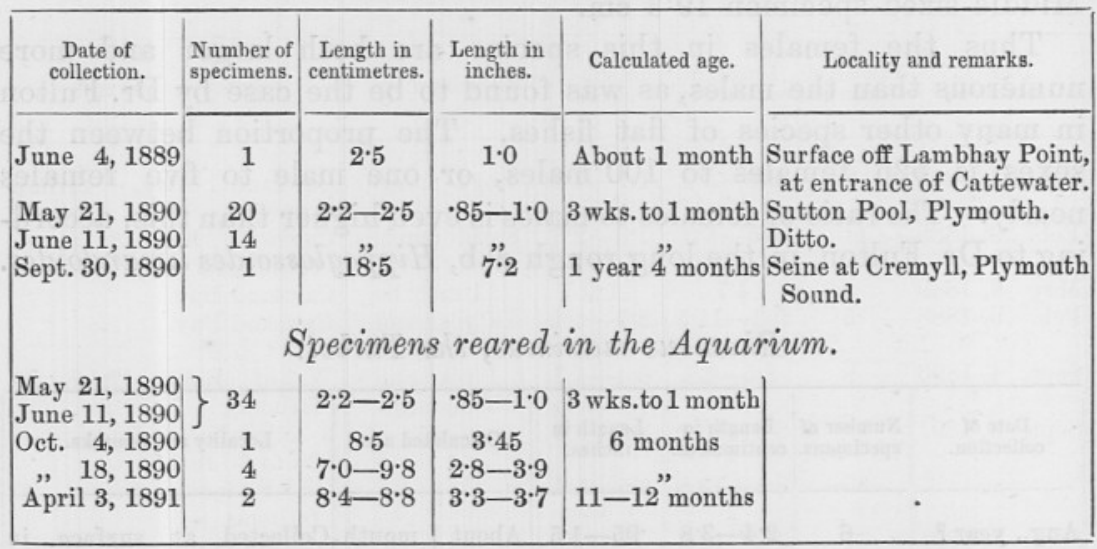

The young brill occur floating at the surface in May and June, at which stage they are in process of metamorphosis, swimming in a slanting or horizontal position, and provided with a large air bladder. They cannot well be less than three weeks old at this stage, and the eggs must, therefore, be shed in April and May. Raffaele believes that at Naples the eggs are shed in February and March, and one would naturally expect the spawning period to be earlier in the Mediterranean.

According to the results observed in the specimens reared in captivity, the growth would seem to be very slow, not exceeding 4 inches in twelve months; but it will be seen from the table that this length was almost reached in six months, so that scarcely any increase in size took place after the first six months. It is probable, therefore, that the growth of my captive specimens was abnormally checked. In nature, these fish feed chiefly on living fish of other species, and I was unable to provide such food for my captive specimens, but fed them on marine worms. On the other hand, I think it unlikely that the specimen obtained in the sea September 30th, 1890, could have reached its length of $7 \cdot 2$ inches in five months, and, therefore, I have considered it to be more than one year old. The adult brill is from 18 inches to 2 feet long, the latter being the maximum length observed. If 7 to 8 inches is the average growth in one year, the growth of the brill would appear to be slower in proportion to its size than that of the flounder, and it would probably take four years to reach a length of 18 inches. Additional data are needed, but I have found it difficult to find specimens of two to twelve months old in the sea. The species is much less common than the plaice, flounder, or dab, and even the adults are only taken sparingly by the professional trawlers. 
Arnoglossus laterna, the Scald-back.

\begin{tabular}{|c|c|c|c|c|c|}
\hline $\begin{array}{c}\text { Date of } \\
\text { collection. }\end{array}$ & $\begin{array}{l}\text { Number of } \\
\text { specimens. }\end{array}$ & $\begin{array}{l}\text { Length in } \\
\text { centimetres. }\end{array}$ & $\begin{array}{l}\text { Length in } \\
\text { inches. }\end{array}$ & Calculated age. & Locality and remarks. \\
\hline Oct. 3,1889 & 2 & $2 \cdot 8-3 \cdot 4$ & $1 \cdot 1-1 \cdot 4$ & 4 or 5 months & Cawsand Bay, shrimp \\
\hline Feb. $\quad 9,1888$ & 11 & $4 \cdot 5-6 \cdot 3$ & $1 \cdot 8-2 \cdot 5$ & 8 or 9 months & $\begin{array}{l}\text { Cawsand Bay, } 3 \text { to } 5 \\
\text { fathoms. }\end{array}$ \\
\hline May 8,1889 & 1 & $4 \cdot 7$ & 1.9 & 11 months & Cawsand Bay. \\
\hline Feb. 9,1888 & 5 & $9 \cdot 3-11 \cdot 5$ & $3 \cdot 7-4 \cdot 4$ & $\begin{array}{l}1 \text { year and } \\
8 \text { months }\end{array}$ & Cawsand Bay. \\
\hline Sept. 4,1890 & 8 & $8 \cdot 5-12$ & $3 \cdot 4-4 \cdot 7$ & $\begin{array}{l}1 \text { year and } \\
3 \text { months }\end{array}$ & $\begin{array}{l}\text { W. of Rame Head, } 20 \\
\text { fathoms. }\end{array}$ \\
\hline Sept. 3,1891 & 19 & $8 \cdot 8-13 \cdot 2$ & $3 \cdot 5-5 \cdot 2$ & " & $\begin{array}{l}3 \text { miles N. of Eddystone, } \\
25 \text { to } 30 \text { fathoms. }\end{array}$ \\
\hline$\sigma^{2}$ & 35 & $8 \cdot 8-13 \cdot 8$ & $3 \cdot 5-5 \cdot 4$ & ", & $\begin{array}{l}\text { Off Plymouth Sound, } 20 \\
\text { fathoms. }\end{array}$ \\
\hline Sept. 8,1891 & 77 & $7 \cdot 8-12 \cdot 6$ & $3 \cdot 1-5$ & ” & $\begin{array}{l}\text { Off Mewstone and Whit- } \\
\text { sand Bay, } 23 \text { to } 27 \\
\text { fathoms. }\end{array}$ \\
\hline Sept. 12, 1891 & 13 & $8-12$ & $3 \cdot 15-4 \cdot 7$ & " & $\begin{array}{l}8 \text { to } 10 \text { miles S. of Eddy- } \\
\text { stone, } 36 \text { to } 38 \text { fathoms. }\end{array}$ \\
\hline Dec., & 43 & $14 \cdot 7-20 \cdot 4$ & $5 \cdot 8-8$ & $\begin{array}{l}\text { Over } 2 \text { years, } \\
\text { adult and } \\
\text { sexually mature }\end{array}$ & $\begin{array}{l}10 \text { to } 20 \text { miles from shore } \\
\text { off Plymouth, from pro- } \\
\text { fessional trawler. }\end{array}$ \\
\hline
\end{tabular}

I do not know exactly the spawning period of this species, but believe it occurs in summer, in May and June; the ages in the above table have been reckoned from June. I have only obtained the very small specimens, less than one year old, in Cawsand Bay, at 3 to 5 fathoms depth, in the small shrimp trawl. In September of the current year I obtained large numbers of the species, 7 to $14 \mathrm{~cm}$. long, in an otter trawl, both inside and outside the Eddystone, at depths varying from 20 to 38 fathoms. I think it is impossible that these should be derived from this year's spawning, since small specimens, less than $4 \mathrm{~cm}$. long, and evidently a few months old, were taken in Cawsand Bay in October. It follows, therefore, that the specimens taken in September, 7 to $14 \mathrm{~cm}$. long, are in their second year. The adult condition in this species is distinctly marked in the male sex by the sudden elongation of the anterior dorsal fin-rays which occurs when sexual maturity is reached, and which I have observed only in specimens over $14 \mathrm{~cm}$. in length. The largest specimens I have seen were $20.4 \mathrm{~cm}$. long. I have only obtained the adults from the deep sea trawlers, and they were taken at some distance from the coast. There seems, therefore, to be a regular distribution of the different stages, those of the first year occurring in shallow sandy bays, of 3 to 5 fathoms in depth; those of the second year occurring from shallow water to a depth of 36 fathoms, but being especially abundant between 20 and 30 fathoms; 
while the adults occur principally beyond the 30 fathoms line. The adult condition and sexual maturity is not reached till the end of the second year.

Gadus merlangus, the Whiting.

\begin{tabular}{|c|c|c|c|c|c|}
\hline $\begin{array}{l}\text { Date of } \\
\text { collection. }\end{array}$ & $\begin{array}{l}\text { Number of } \\
\text { specimens. }\end{array}$ & $\begin{array}{c}\text { Length in } \\
\text { centimetres. }\end{array}$ & $\begin{array}{l}\text { Length in } \\
\text { inches. }\end{array}$ & Calculated age. & Locality and remarks. \\
\hline June 13,1889 & 2 & $5 \cdot 7$ & $2 \cdot 2$ & 3 or 4 months & Whitsand Bay, 3 to 5 fath- \\
\hline July 16,1891 & 13 & $5 \cdot 4-9 \cdot 0$ & $2 \cdot 1-3 \cdot 5$ & 4 or 5 months & $\begin{array}{l}2 \text { miles S. of Eddystone; } \\
\text { large tow net, } 8 \text { feet by } \\
6 \mathrm{ft} \text {. at mouth; } 11 \text { speci- } \\
\text { mens at } 15 \text { fathoms from } \\
\text { surface, } 2 \text { at } 6 \text { fathoms. } \\
\text { These were all the whiting } \\
\text { caught. }\end{array}$ \\
\hline
\end{tabular}

The second entry shows that the young whiting, from eggs spawned the previous spring, occur not only in shallow bays close to the bottom, but also at some distance from land in mid-water. The whiting at Plymouth spawns in February and March. I think there can be no doubt that these whiting were under six months old, and were hatched in the previous March, and that they were not in their second year. Dr. Fulton describes the occurrence of a great shoal of young whitings, from 2 to 5 inches in length, in September ; these young fish were so numerous that over 3000 were taken at a single haul of an 18 foot beam-trawl. Dr. Fulton seems unable to account for the origin of this shoal, apparently rejecting the obvious idea that the fish comprising it were hatched the previous spring. $\mathrm{He}$ says the whiting spawns in March, April, May, and June, and that a pelagic specimen, 1 inch long, has been captured by the tow-net in September, by Prof. McIntosh. Now, according to my own experience, the whiting spawns in the Firth of Forth and neighbouring sea, principally in April, and young fish hatched in April cannot be only 1 inch long in September, when five months old. I think the various observations I have here brought together with regard to other species show, conclusively, that the whiting mentioned by Dr. Fulton, from 2 to 5 inches in length in September, were hatched in the preceding April and May. 
Gadus pollachins, the Pollack.

\begin{tabular}{|c|c|c|c|c|c|}
\hline $\begin{array}{l}\text { Date of } \\
\text { collection. }\end{array}$ & $\begin{array}{l}\text { Number of } \\
\text { specimens. }\end{array}$ & $\begin{array}{c}\text { Length in } \\
\text { centimetres. }\end{array}$ & $\begin{array}{l}\text { Length in } \\
\text { inches. }\end{array}$ & Calculated age. & Locality and remarks. \\
\hline Apr. 3, 1890 & 22 & $2-2 \cdot 4$ & $\cdot 8-95$ & 3 to 6 weeks & $\begin{array}{l}\text { Taken with hand-net in } \\
\text { Mevagissey Harbour. }\end{array}$ \\
\hline Oct. 2,1890 & 10 & $9 \cdot 7-11 \cdot 2$ & $3 \cdot 8-4 \cdot 4$ & 7 months & $\begin{array}{l}\text { Taken in cheesecloth trawl, } \\
\text { Cawsand Bay, } 3 \text { to } 5 \\
\text { fathoms. }\end{array}$ \\
\hline Dec. 4, 1889 & 4 & $9 \cdot 3-11 \cdot 8$ & $3 \cdot 7-4 \cdot 7$ & 9 months & $\begin{array}{l}\text { Taken from the dry dock } \\
\text { at Millbay when the dock } \\
\text { was emptied. }\end{array}$ \\
\hline
\end{tabular}

I have not myself made any observations on the spawning of the pollack, but there can be no doubt that it spawns early in the year, in February and March. It may also be assumed that the ova are pelagic and buoyant. The few data given in the table are not sufficient to show the rate of growth with certainty, but I think they may be trusted as far as they go. It may be inferred that 7 inches is about the maximum growth for one year. The pollack caught in Plymouth Sound in June and July are 12 to 15 inches in length. These are, I believe, over two years old. The fish grows to more than 2 feet in length. I have no evidence to show whether it begins to breed when only one year old or not. The pollack is a coast fish, and its young seem always to be found in shallow water, in bays and inlets, and in the neighbourhood of rocks and piers. It is seldom, though occasionally, taken in the trawl, as it feeds mostly in mid-water, not on the bottom, and usually occurs in the neighbourhood of rocks and weeds.

Gadus luscus, the Pout or Bib.

\begin{tabular}{|c|c|c|c|c|c|}
\hline $\begin{array}{l}\text { Date of } \\
\text { collection. }\end{array}$ & $\begin{array}{l}\text { Number of } \\
\text { specimens. }\end{array}$ & $\begin{array}{c}\text { Length in } \\
\text { centimetres. }\end{array}$ & $\begin{array}{l}\text { Length in } \\
\text { inches. }\end{array}$ & Calculated age. & Locality and remarks. \\
\hline Sept. 5, 1890 & 11 & $6 \cdot 4-7 \cdot 7$ & $\begin{array}{c}2 \cdot 5-3 \cdot 0 \\
4 \cdot 6\end{array}$ & 6 months & $\begin{array}{l}\text { Whitsand Bay, } 3 \text { to } 5 \text { fath- } \\
\text { oms; small-meshed trawl } \\
\text { at night. } \\
\text { Cawsand Bay; shrimp }\end{array}$ \\
\hline $\begin{array}{r}\text { Oct. } 2,1890 \\
\text { June } 17,1889\end{array}$ & $\begin{array}{l}2 \\
1\end{array}$ & $\begin{array}{c}10 \cdot 7-13 \cdot 0 \\
12.5\end{array}$ & $\begin{array}{c}4 \cdot 2-5 \cdot 1 \\
4 \cdot 9\end{array}$ & $\begin{array}{c}7 \text { months } \\
1 \text { year } 2 \text { months }\end{array}$ & $\begin{array}{l}\text { Ditto. } \\
\text { Whitsand Bay; small- } \\
\text { meshed trawl. }\end{array}$ \\
\hline
\end{tabular}

This species grows to about 1 foot in length, and we may judge from the last entry in the table that its size at the end of the first year is 5 to 6 inches. In June it is 2 to 3 inches in length, and at 
this stage I have taken it, though sparingly, in shallow water in Whitsand Bay. Specimens in their second summer, just over one year old, are abundant in June and July in Plymouth Sound and elsewhere along the coast in shallow water, and are taken in numbers by hook and line. Specimens of the same age and about 6 inches long are also taken by the deep-sea trawlers in depths up to 30 fathoms. I have as yet, however, made only the above records.

Gadus minutus, the Poor Cod.

\begin{tabular}{|c|c|c|c|c|c|}
\hline $\begin{array}{c}\text { Date of } \\
\text { collection. }\end{array}$ & $\begin{array}{l}\text { Number of } \\
\text { specimens. }\end{array}$ & $\begin{array}{l}\text { Length in } \\
\text { centimetres. }\end{array}$ & $\begin{array}{l}\text { Length in } \\
\text { inches. }\end{array}$ & Calculated age. & Locality and remarks. \\
\hline May 28,1890 & 12 & $2 \cdot 8-4 \cdot 3$ & $1 \cdot 1-1 \cdot 7$ & $8-12$ weeks & Shrimp trawl, in Catwater. \\
\hline June 17, 1889 & 218 & $4 \cdot 2-7 \cdot 2$ & $1 \cdot 6-2 \cdot 9$ & About 3 months & $\begin{array}{l}\text { Small-meshed trawl, in } \\
\text { Whitsand Bay, } 5 \text { to } 7 \\
\text { fathoms, at night. }\end{array}$ \\
\hline July 9,1891 & 6 & $11 \cdot 5-16 \cdot 2$ & $4 \cdot 5-6 \cdot 4$ & 1 year 3 months & $\begin{array}{l}\text { Taken in shrimp trawl, } 2 \\
\text { miles north of Eddystone, } \\
27 \text { fathoms. }\end{array}$ \\
\hline April 19, 1891 & 7 & $14 \cdot 3-19 \cdot 0$ & $5 \cdot 6-7 \cdot 5$ & 2 years & $\begin{array}{l}\text { The smallest specimens } \\
\text { taken by a professional } \\
\text { trawler to the east of Ed- } \\
\text { dystone, } 30 \text { fathoms. }\end{array}$ \\
\hline June 17, 1889 & $\begin{array}{l}2 \\
1\end{array}$ & $\begin{array}{c}13 \cdot 7-15 \cdot 0 \\
20 \cdot 0\end{array}$ & $\begin{array}{c}5 \cdot 4-5 \cdot 8 \\
7 \cdot 8\end{array}$ & $\begin{array}{l}1 \text { year } 2 \text { months } \\
2 \text { years } 2 \text { months }\end{array}$ & $\left\{\begin{array}{l}\text { Small meshed trawl, } \\
\text { Whitsand Bay, 5 to } 7 \\
\text { fathoms, at night. }\end{array}\right.$ \\
\hline
\end{tabular}

The observations on this species are very inadequate, but they supply some definite facts. The occurrence of more than two hundred specimens less than 3 inches long in Whitsand Bay, undoubtedly from ova shed the preceding spring, shows that the young frequent shallow water and sandy ground. It is also clear that the specimens, $4 \cdot 5$ to $6 \cdot 4$ inches, obtained on July 9 th, near the Eddystone, were in their second year. I have not ascertained at what size the species begins to breed. But specimens of 4 to 6 inches, and just over a year old, were caught in the Sound and placed in our tanks in the summer of 1889, and were breeding there in March, 1890. I am pretty sure this was their first time of breeding. I am not quite sure as to the size attained in two years, but as the rate of growth in length decreases gradually, I think those of April 19th, 1891, in the table, must have been two years old. The poor cod never exceeds 9 inches in length. 
Zeus faber, the Dory.

\begin{tabular}{|c|c|c|c|c|c|}
\hline $\begin{array}{l}\text { Date of } \\
\text { collection. }\end{array}$ & $\begin{array}{c}\text { Number of } \\
\text { specimens. }\end{array}$ & $\begin{array}{c}\text { Length in } \\
\text { centimetres. }\end{array}$ & $\begin{array}{l}\text { Length in } \\
\text { inches. }\end{array}$ & Calculated age. & Locality and remarks. \\
\hline Oct. 3,1889 & 1 & $4: 3$ & $1 \cdot 7$ & About 3 months & 8 Cawsand Bay, 3 to 5 \\
\hline June 3,1889 & 3 & $12 \cdot 5-14 \cdot 1$ & $4 \cdot 9-5 \cdot 5$ & 11 months & $\begin{array}{l}\text { fathoms; shrimp trawl. } \\
3 \text { miles from Rame Hea }\end{array}$ \\
\hline & & & & & $\begin{array}{l}20 \text { fathoms; small-meshed } \\
\text { trawl. }\end{array}$ \\
\hline Aug. 20, 1891 & 7 & $13 \cdot 5-15 \cdot 6$ & $5 \cdot 3-6 \cdot 1$ & 1 year and & 5 miles S. of Eddystone; \\
\hline Sept. 8, 1891 & 2 & $17 \cdot 2,17 \cdot 5$ & $6 \cdot 8,6 \cdot 9$ & $\begin{array}{l}1 \text { year and } \\
2 \text { months }\end{array}$ & $\begin{array}{l}\text { Whitsand Bay, } 5 \text { fathoms; } \\
\text { otter trawl. }\end{array}$ \\
\hline " & 1 & $16 \cdot 6$ & 6.5 & " & S. W. of Rame Head, 20 \\
\hline Sept. 18, 1891 & 5 & $14-18 \cdot 5$ & $5 \cdot 5-7 \cdot 3$ & " & $\begin{array}{l}5 \text { to } 8 \text { miles S. of Eddystone; } \\
\text { professional trawler. }\end{array}$ \\
\hline Apr. 21, 1891 & 1 & $24 \cdot 5$ & $9 \cdot 6$ & $\begin{array}{l}1 \text { year and } \\
10 \text { months }\end{array}$ & $\begin{array}{l}\text { S.E. of Eddystone, } 35 \\
\text { fathoms ; professional } \\
\text { trawler. }\end{array}$ \\
\hline Sept. 3, 1891 & 1 & $28 \cdot 2$ & $11 \cdot 1$ & $\begin{array}{l}2 \text { years and } \\
2 \text { months }\end{array}$ & $\begin{array}{l}\text { S. of Rame Head, } 25 \\
\text { fathoms; otter trawl. }\end{array}$ \\
\hline
\end{tabular}

Although the above table includes but a small number of specimens, I believe that it represents with considerable certainty the growth of the dory. I do not know exactly when the dory spawns, but I have examined the adults in spring and found the ovaries ripening, and in autumn have found them shotten, so that I conclude the spawning takes place about June and July. In the table I have reckoned the ages from July. It will be seen that specimens from 5 to a little over 7 inches in length are fairly common in August and September, and since young specimens of 1 to 2 inches in length occur in autumn, it is evident that the former are just over one year old, while the latter are derived from eggs shed in the preceding summer. The last specimen in the table is, I think, too large to be only one year old, and I therefore judge it to be in its third year. The largest dory mentioned by Day was $22 \frac{1}{2}$ inches long, but the usual size is from 15 to 18 inches, which is probably not reached in less than three years.

\section{Motella mustela, the Five-bearded Rockling.}

In this Journal, vol. i, p. 372, I mentioned some specimens of this species kept in the Aquarium from May to August, 1890. All except one of these were placed in a large tank and have not been seen again, but the remaining specimen was measured alive on May 19th, 1891, when just over a year old, and found to be 13.0 cm., or $5 \cdot 1$ inches long. Measured again on September 21st, it

NEW SERIES.-VIJL. II, NO. 2. 
was exactly the same length. In the tank with it were several vigorous flounders, and probably this was the reason that it had not grown, the flounders having seized all the food put in the tank. But numbers of this species, 5 to 7 inches in length, occur under rocks, between tide-marks, in summer, which are obviously at the commencement of their second year. This species reaches $18 \mathrm{in}$. in length, and does not change colour when adult. $\mathrm{My}$ young specimen, like the adult, is a dark rich brown on the sides, black on the back, white on the ventral surface.

\section{Motella tricirrata, the Three-bearded Rockling.}

On June 20th of the present year I went out for a fishing trip in a mackerel boat, and when we got as far as the Mewstone it fell dead calm, and remained so for some hours. The surface of the sea was covered with great quantities of Noctiluca miliaris, here and there collected in patches and streaks into a thick scum of a salmonpink colour. Darting about at the surface were numerous small active fishes, of which I secured a great number, and found on examining them ashore that they were the young of Motella tricirrata, the three-bearded rockling. These young fish were swimming at the very surface of the water, causing it to ripple by their motion. Fishermen at Plymouth call all such young fish " britt," not distinguishing one species from another. The older naturalists described this young form as a distinct species, and Couch calls it the mackerel-midge.

Among my specimens there are three stages to be distinguished, which pass gradually into one another. The oldest stage is from 2.5 to $3.2 \mathrm{~cm}$. long. ( 1 to 1.3 inch), and is closely similar to the adult, except that the sides are brilliantly silvery, which is not the case in the adult. In this stage the fins are all similar to those of the adult, the pelvic reaching only half way to the anus. The youngest stage is under $1 \mathrm{~cm}$. in length, and the skin is almost transparent, the silvery opacity commencing to develop in the largest specimens. There are pigment cells, especially on the back. The fin-rays have only recently begun to develop and are not complete at their distal ends; the anterior dorsal fin is not visible, but the principal peculiarity is the pelvic fins, which are comparatively long, extending beyond the anus, and having a dense black colour over their outer halves. The second stage is intermediate between these in all respects: it is from 1 to $2.5 \mathrm{~cm}$. in length, and in the different specimens in this stage can be traced the development of the silvery layer in the skin, and of the anterior dorsal fin, and the gradual reduction of the pelvic fin. A specimen of the young 
Motella in the second of the stages above mentioned, is described and figured in my paper in this Journal, vol. i, p. 47.

\section{Caranx trachurus-the Scad, or Horse-mackerel.}

This is a pelagic species frequently taken in mackerel nets. Its young are also pelagic, and I have taken them in the tow-net in August and September. In August, 1888, one $5 \cdot 4 \mathrm{~cm} .(2 \cdot 1$ inches) was taken three or four miles off Loae. On September 8th this year I took two, 2.4 and $3.5 \mathrm{~cm}$. long, to the south-west of the Mewstone; and on September 12th, one $2.5 \mathrm{~cm}$. long, about five miles south of the Mewstone.

\section{Comparisons and Conchusions.}

1. Flat fishes.-If we consider first the species of the genus Pleuronectes alone we find some curious and interesting differences. We find that the flounder and plaice when immature, that is under 7 and 9 inches respectively in length, and less than two years old, are almost entirely absent beyond the 20 fathom line. The young of these two species are abundant in the estuaries of Cattewater and the Hamoaze. In June, 1889, I found plaice 1 to 3 inches long, spawned the previous spring, in abundance in Whitsand Bay, which is not an inlet, but a bay open to the sea; but during the present summer, I have trawled there several times in July and September and found no young plaice at all. On the other hand, the dab (Pl.limanda), even under one inch in length and only three months old, occurs, though not abundantly, near the 30 fathom line, a little inside the Eddystone. It is much more abundant at this age in Cawsand and Whitsand Bays, at depths of 3 to 7 fathoms. $\mathrm{Up}$ to 5 inches in length it is common in the Cattewater, where also larger specimens are not uncommon. The trawlers working off Plymouth between 20 and 40 fathoms bring up numbers of small flat fishes, but, with very few exceptions, these are all dabs or scaldbacks, Arnoglossus laterna. The smallest dabs I have obtained from the trawlers were $4 \frac{1}{2}$ inches long, a length which may be reached by some individuals at one year of age. Thus, although specimens of less size and age than this are not uncommon at depths of 10 to 30 or 40 fathoms, the great beam trawl does not catch them because its meshes are too large. I have not kept records of the small scald-backs brought up by the great beam trawl, though when studying other subjects on board trawlers I have seen numbers of them brought up. During the present summer, however, when fishing 
with an otter-trawl myself, on purpose to obtain young fish, I have obtained large numbers of this species from 3 to 5 inches in length. I find that specimens of this size are between one and two years in age, are not sexually mature, and are distributed at all depths from 3 to 40 fathoms.

Pleuronectes microcephalus, the merry-sole, is the only other species of the genus usually met with near Plymouth. There is no doubt that the young, under 6 inches long, and less than one year old, are entirely absent from shallow water, under 10 fathoms, and from inlets and estuaries. No destruction of the young of this species can be effected by shrimp, or seine, or bag-net fishing in territorial waters. As far as my observations go, the professional deep-sea trawler does not capture the young of this species under 6 inches, but on this point I have collected very few data up to the present time. It is, however, certain that the species belongs to rather deep water ; it is scarce at less than 30 fathoms, and abundant at greater depths. I have not yet obtained any specimens under 6 inches long, but Dr. Fulton obtained three specimens, 2 inches long, at about 20 fathoms. I have not met with any such specimens in my numerous hauls with small-meshed trawls this summer inside the Eddystone. I am inclined to think that most of the young of this species, when they go to the bottom, remain in deep water beyond the 30 fathom line.

I have not yet found young soles between $\frac{1}{2}$ inch and 6 inches in length, although I have specially searched for them at various depths up to 35 fathoms. My evidence concerning this species is similar to that concerning the brill and turbot; in all three cases I have found the very young forms only a few weeks old close to the shore in harbours and inlets, and have taken other specimens much larger and about one year old in territorial waters within the 10 fathom line.

With regard to the age of sexual maturity, I have proved that a large number of individuals do not reach the minimum size of mature specimens at the end of one year, and that it is quite probable that all flat fishes normally breed for the first time when two years old.

2. Other species. - It will be seen that the young of all the species of Gadus mentioned above, namely the whiting, pollack, pout, and poor-cod, for the first six months of their existence are found close to the shore, the fry of the pollack and poor-cod seeking harbours and estuaries, and being seen in numbers swimming about near piers and wharves. When about one year old, these kinds of fish are found in abundance at depths of 5 to 30 or more fathoms. The pollack haunts rocky shores all its life, and only very large 
specimens, 12 inches to 2 feet long, are occasionally taken in the great trawls, but of the other species many one-year-old individuals are destroyed by them. It is remarkable also how commonly oneyear-old dorys are taken in the deep-sea trawls.

\section{Practical Considerations.}

A great deal of work remains to be done before we obtain an adequate knowledge of the life-histories of our valuable sea fishes. I hope to continue my own observations in various directions, and in future to add largely to the data recorded above. But in the meantime the question of the harm done to our sea fisheries by the destruction of under-sized or immature fish is constantly being agitated, and cannot be too carefully considered. Our national statistics show that our best sea fish are getting scarcer. It seems at first sight the irony of fate that the finest fish such as sole, turbot, brill, and dory should be scarce, while inferior kinds such as dabs are plentiful, and worthless kinds such as scald-fish and dogfish are still more abundant. The case of the sole is difficult to explain. It feeds on worms chiefly as do the plaice and flounder, yet it is by no means so plentiful as the plaice. One might be tempted to maintain that the sole is really no better intrinsically than the plaice, but only valued more because it is dearer. But a moment's consideration of the difference between the flesh of the two is enough to dispel such an idea. In the case of the turbot, brill, and dory, however, there is a reason why they are relatively scarce. These fishes, compared with many other kinds, are as the Carnivora to the Herbivora on land. They feed exclusively on other fishes. They are fishes of prey, and must, therefore, as in the case of other Carnivora, exist in smaller numbers than the fish they prey upon. Perhaps some day we shall also be able to understand why the sole is less abundant than the plaice.

But the practical question is how to prevent the decrease in the supply of fishes whatever their natural numerical proportions to one another, and one obvious precaution is to prevent as far as possible the destruction of the young. I will, therefore, here indicate the bearings which my observations at Plymouth have upon this practical question. Dr. Fulton, throughout the whole of his inquiry, has interpreted the term immature fish as meaning a fish not yet capable of reproduction. The fishermen of the east coast, who have been so strongly moved on the subject of immature fish, knew nothing and cared nothing about the size at which a fish of a certain kind began to breed. What they were thinking of was the fact that if all the small fish were caught there were none left to grow large, and con- 
sequently, as the large fish were more valuable per pound, their work became less remunerative. Dr. Fulton evidently thinks that a fish ought not to be destroyed before it has spawned at least once, and that if it is sexually mature there can be no harm in capturing it. Thus he would only preserve lemon soles ( $P l$. microcephalus) up to 8 inches, while the fishermen wanted to place the limit at 12 inches. Theoretically I am more in agreement with the fishermen on this point than with Dr. Fulton. It seems to me that the mere fact that a fish at a certain small size is capable of breeding, is not a reason for capturing it if its full-grown size is very much larger. Salmon parr in our rivers are sexually mature, at least the males are when only a few inches long, but their capture is prohibited nevertheless. If it were possible to limit the capture of each sea fish to those above a certain size, I think the limit should be determined by the size of the full-grown fish, and not by the size at which it begins to breed. At the same time the limit should not be fixed below the minimum size of sexually mature individuals.

However, it is not possible to fix a different limit of size for each species of fish captured by the deep-sea trawlers. The only differences in the smallest sizes caught with a given mesh will be due either to differences in the distribution of the young of the several species, or to differences in the shape of the fish. Thus a sole, 10 inches long, could escape through a mesh say 3 inches square, while a turbot, brill, or dory of the same length could not, because the latter three fish are so much broader than a sole in proportion to their length. All that is practically feasible in the case of the deep-sea trawl is to increase the size of the mesh so as to allow more small fish of whatever kind to escape.

The destruction of under-sized fish in the neighbourhood of Plymouth may be described under two heads: (1), that which is due to the deep-sea trawlers; (2), that which is due to inshore fishing. The deep-sea trawlers capture large numbers of under-sized soles, lemon-soles, dorys, dabs, pout, whiting, and gurnard. The dabs are, perhaps, of no great importance, but the young pout and poor-cod (G. luscus and G. minutus) form an important part of the food of the turbot, as I know from examination of the stomachs of the latter. None of these young fish are of much value in the market. Some of them are sold separately, and the proceeds are by custom allowed to the crew as perquisites. If the mesh of the trawl were enlarged these small fish would not be caught. The mesh at the cod-end is now $1 \frac{1}{2}$ inches square, and at the mouth, 4 inches. I believe that the mesh ought to be not less than 3 inches square at the cod-end, and I think that this change would have the additional advantage of allowing much of the useless material known here as 
"scruff" to escape. However, together with the scruff, on certain grounds large quantities of so-called queens (Pecten opercularis) are taken, and these are eaten to a considerable extent by the poorer people. These would probably not be caught by a 3-inch mesh, and their loss would have to be considered. I do not believe that it would be of much use to return to the sea the under-sized fish taken in the deep-sea trawl, leaving the mesh unaltered. It is true that most of the small fish are alive when brought on deck; they flap about and move when touched, but by the pressure of the great mass that the trawl contains, the violent concussions of this mass against the sides and bulwarks of the vessel, the sudden fall of the mass on deck when the end of the trawl is opened, and the trampling of the heavy boots of the crew as they handle the gear, the majority of the small fish are so much injured, especially in rough weather, that a great many of them would die sooner or later if thrown overboard.

The inshore fishing which destroys young fish consists principally of shrimp-trawling, fishing with small fish-trawls, and ground-seining. The shrimp trawls in Plymouth Sound take numerous small soles which ought not to be taken. This would be prevented if it were made illegal to keep them, because these fish are not in the least injured when brought up in the trawl. The ground-seines destroy large numbers of small plaice and flounders in the Cattewater and Hamoaze, but I have been informed by Mr. Henry Clark, who holds exclusive fishing rights in the upper part of the Cattewater, that fish of all kinds have grown very scarce there in recent years, probably, in his opinion, in consequence of the pollution of the estuary by manure and china-clay refuse. The ground-seines are used chiefly for the purpose of catching mullet and bass, and there would be no difficulty in compelling the fishermen who use them to return small flat fishes to the water, for these fishes are not injured in the process of capture by this method. The small fish trawls are worked by small sailing-boats in Whitsand Bay and Bigbury Bay. Their most valuable produce consists of small turbot and brill, and they take more under-sized fish of all kinds in proportion to the total catch than the deep-sea trawls. I think this kind of fishing should be prohibited altogether, at least in certain areas. The inshore bays should be strictly preserved as nurseries for young plaice, dorys, turbot, and other fish, which are at present captured in them. The Cornwall County Council has passed a bye-law prohibiting steam trawling in territorial waters within its district. It seems to me that this is a perfectly justifiable measure in relation to what it does, but not in relation to what it leaves undone. Small steamers, and tugs at times, when they are not employed in their 
proper work, are on many parts of the coast used for trawling in bays and inshore waters, and are very destructive on account of the ease with which they are handled. It is a good thing, therefore, that this kind of fishing should be prohibited, but it is inconsistent and unreasonable to allow sailing boats to do that which steamers are prohibited from doing. 